\title{
Income growth in the United Kingdom during late career and after retirement: growing inequalities after deindustrialisation, educational expansion and development of the knowledge-based economy
}

\author{
Alberto Veira-Ramos ${ }^{1 \star}$ (iD) and Paul Schmelzer ${ }^{2}$ \\ ${ }^{1}$ Departamento de Análisis Social, Universidad Carlos III de Madrid, Madrid, Spain and ${ }^{2}$ Deutsches \\ Institut für Wirtschaftsforschung (DIW), Berlin, Germany \\ *Corresponding author. Email: alberto.veira@uc3m.es
}

(Accepted 12 April 2021; first published online 28 May 2021)

\begin{abstract}
This article shows how late-life incomes from work and pensions evolved in the United Kingdom between 1991 and 2007, the year the Great Recession began. Our main contribution comes from focusing on changes across cohorts in different educational groups while also considering the gender divide. Our statistical analyses based on the British Household Panel Survey (BHPS) suggest that deindustrialisation, the expansion of jobs in the knowledge economy and pension reforms affected senior workers' incomes before and after retirement. Highly qualified senior male workers have profited from increasing income across the cohorts more than any other social group. Such a trend is not observed among highly qualified female workers. Male and female low-qualified senior workers do not show major income loses, but have not benefited to the same extent as highly educated male workers. As a result, pension income inequalities between highly qualified men and the rest have increased. The increasing pensions gap between educational groups can be traced back to the improving situation on the labour market for highly qualified male workers, and to reforms benefiting private pension schemes, where the highly qualified are overrepresented. Thus, the shift in pension provisions towards private pension schemes is clearly disadvantageous for low-qualified male workers and for women of all educational levels, and contributes to the increase of social inequalities.
\end{abstract}

Keywords: ageing; income inequalities; gender inequalities; pension income; deindustrialisation; knowledge-based economy

\section{Introduction}

From the mid-1990s until the Great Recession of 2008, increasing globalisation of markets and the development of new information technologies leading to the 
expansion of the knowledge economy (Foray and Lundvall, 1998) provoked major changes in the British labour market. In order to respond to changes, and conditioned by the rhetoric around the potential consequences of demographic ageing, a series of British governments have sought to redress their public pension policies (Reynaud, 2000), aiming to reduce dependence on public provisions provided by the State Earnings-Related Pension Scheme (SERPS) and encourage self-reliance among senior workers to secure adequate retirement income (Lain, 2016). Moreover, increasing participation of women in the labour market added complexity to the picture of senior employment and retirement, because women's typical career patterns differ from those of men in several crucial respects (Loretto and Vickerstaff, 2015).

Countries with liberal regimes such as the United Kingdom (UK) are often characterised by high efficiency in implementing new and innovative forms of business and entrepreneurship, and comparatively high individualisation of risks due to their strong free-market orientation (Hall and Soskice, 2001; Witt and Jackson, 2016). In line with what one might expect based on such traits, the UK has adapted faster to the new challenges arising from an increasingly globalised economy. Indeed, the UK was one of the most successful European countries in reaping the benefits of the new, developing sector of information technologies and the knowledge economy (Dunning, 2002).

On the 'not-so-bright' side, the UK has also been a country whose manufacturing sector has been hit harder by deindustrialisation than other developed economies (Coates and Hillard, 1986; Kitson and Michie, 1996; Alderson, 1999).

British governments have also been inclined to liberalise markets and undertake sweeping reforms of basic welfare state structures. Indeed, the UK was among the first countries to announce an ambitious pension reform plan (Disney and Emmerson, 2005), deeper than those implemented in almost any other European country (Falkingham, 1989; Walker and Foster, 2006). With the growing discussion of demographic ageing, British governments began to limit possibilities for early retirement, reducing the generosity of public pensions and introducing private pension schemes (Feldstein and Siebert, 2009). This created a great deal of uncertainty for the working population around later life and retirement.

All these factors make British society a highly interesting case study for assessing the impacts of key changes in senior workers' and pensioners' lives as well as a potential example for policy makers in other countries with comparable systems. In this context, our research assesses whether deindustrialisation and the boom in the knowledge economy in the UK have led to increasing inequality in later-life income between the highly educated and those without university education across birth cohorts between 1991 and 2007. We limit the period of our analyses to the year before the Great Recession began to avoid the entanglement of the effects of the above-mentioned trends with the effects of the Great Recession on employment conditions and wages (Gregg and Wadsworth, 2010; Coulter, 2016; Elsby et al., 2016). We also examine the extent to which pension reforms in the UK have exacerbated (or reduced) inequalities after retirement during the two decades of steady economic growth preceding the Great Recession. We also discuss how all these social processes and reforms have affected the gender divide.

This article is structured as follows. First, we describe the three crucial social changes that have affected the lives of senior workers in the UK, situating these 
changes within the larger historical context: deindustrialisation, the development of the knowledge economy, and educational expansion and pension reform. Second, we provide additional insight on each of those changes and discuss their combined impact on the gender divide. Third, based on observed trends, we establish our hypotheses and describe the methodology used in our analyses, which relies on statistical panel data from the British Household Panel Study (BHPS). We conclude by presenting our findings, followed by our conclusions and a final discussion.

\section{Historical background}

The UK has undergone significant socio-political changes since Margaret Thatcher took office in 1979: product and service markets have been liberalised, labour markets deregulated, trade union influence limited, taxes reduced and social benefits curtailed. Although the consequences of these reforms for labour markets are widely acknowledged, the transformation from an industrial economy into a knowledge-based economy, driven and accompanied by globalisation, may have played an equally prominent role in the restructuring of the labour market (Alderson, 1999; Blossfeld et al., 2008). As in most countries in the Organisation for Economic Co-operation and Development (OECD), there has been a significant change over recent decades in the skills profiles that are in demand in the UK (Blossfeld and Buchholz, 2011). Researchers explain these shifts in demand primarily in terms of economic restructuring, technological changes, changes in the organisation of work and growing international trade (Castells, 2000). These factors induced employers to shift employment risk on to employees (Breen, 1997). The inherent dynamics of unco-ordinated market economies, which are characteristic of liberal societies such as the UK (Soskice, 1999; Regini, 2000), further intensified this trend. The influence of trade unions was reduced, and the collective bargaining system was abolished, which opened the path for flexible wage bargaining. Furthermore, the radical commercialisation of the public sector caused many organisations to exchange secure for insecure contracts and to outsource workers or to transfer traditional work to own-account workers (Ladipo and Wilkinson, 2002). According to the Office for National Statistics (ONS), the number of part-time workers increased among senior male employees of 55-64 years of age from $157,000(10 \%)$ in 1993 to $381,000(16 \%)$ in 2008 . Figures for senior women show a decrease in percentages but an increase in absolute numbers: from $666,000(60 \%)$ in 1993 to $957,000(53 \%)$ in 2008. Temporary employment among British employees aged 50 and older increased between 1990 and 2000 among both men and women (from 4.1 to $6.2 \%$ and from 5.5 to $6.2 \%$, respectively) but decreased between 2000 and 2008 to 3.8 and 4.1 per cent, respectively. Nonetheless, changes outlined above were not distributed equally among the different categories of workers, resulting in significant differences in labour income and pension income in late working life.

\section{Deindustrialisation and industrial restructuring}

Up to 1970, there was a strong demand for skilled and semi-skilled workers in the manufacturing sector. Since then, the British economy has witnessed the most 
dramatic decline in traditional industries of any OECD country: the near disappearance of the coal industry in the 1980s, a serious decline in train manufacturing plants, as well as the decline of the shipbuilding and car manufacturing industries (Kitson and Michie, 1996; Black, 2004).

In contrast to the rest of the OECD countries, in the UK the increasing productivity of manufacturing jobs did not compensate for the declining share of manufacturing jobs: the British manufacturing sector has experienced 30 years of almost stagnant per capita output. In comparison to the manufacturing sector, the knowledge-based service sector (finance and business services such as consulting and computer and information services) has increased significantly in productivity over the past few decades (Rowthorn and Coutts, 2004). This in turn has led to the further devaluation of jobs in traditional industries. Indeed, non-service employment is one of the lowest paid sectors in the UK. For comparison, the non-service sector in Germany was the second best paid sector, ranking just below the business sector (Fagan et al., 2005). Trade with low-wage export countries accelerated the declining demand for unskilled work further. Rowthorn and Coutts (2004) found out that between 1970 and 1994, for every four to five manufacturing jobs that were lost, there was an average of one new manufacturing job created through the export of high-skill-based manufactured goods.

According to the ONS, 6.7 million British workers were employed in the 'manufacturing sector' in 1978. The figure decreased to 2.7 million in 2009, remaining stable around that number ever since. In contrast, those employed in the 'accommodation and food service activities' increased from around 1.17 million in 1978 to 2 million in 2009 (reaching 2.5 million in 2019). Employment in the 'wholesale and retail trade' also increased from 3.9 million jobs in 1978 to almost 5 million in 2001, remaining stable around that figure ever since.

Moreover, although the decline in traditional industries was accompanied by an increase in service jobs available to low-qualified workers (Felstead et al., 2007), ${ }^{1}$ such low-skilled service jobs have hardly been a promising alternative for redundant male industrial workers in terms of stability, working hours or wages (Fagan et al., 2005).

The average total weekly earnings of those employed in the 'wholesale and retail trade' and in 'accommodation and food service activities' were $£ 209$ in 2001 and $£ 285$ in 2009 (a $36.4 \%$ increase). In contrast, earnings of those employed in the 'manufacturing sector' increased from $£ 363$ to $£ 491$ (35.3\%) during the same period.

Given these trends, one could assume that the decline of employment in the manufacturing sector not only limited the employability of senior workers without tertiary education but also implied a decline in their average earnings. There is recent evidence that, in fact, British employers have been actively recruiting senior workers of 60 years of age and over, to work in low-paid jobs, often under part-time contracts, requiring low levels of qualification (Lain, 2012).

\section{The knowledge economy and educational expansion}

The British economy has been successful in securing a leading global role in the field of high-quality services (finance and business services such as consulting, 
computers, advertising, etc.) that require highly trained and mobile professionals (Shavit and Blossfeld, 1993). Since the beginning of the 1980s, constant improvements in productivity in this sector have favoured the increase in the number of high-skilled service jobs (professional and managerial) to approximately $40 \mathrm{per}$ cent of all employment (Fagan et al., 2005). According to the ONS, the number of British workers employed in 'professional, scientific and technical activities' increased from 0.96 million in 1978 to 2.4 in 2009 (reaching 3.2 million in 2019). A similar trend was observed among those employed in 'administrative and support service activities': 1 million in 1978 and 2.3 in 2009 (reaching 3 million in 2019). If we focus on the sectors most closely linked to the development of the knowledge economy, such as those in the 'information and communication sector', the figures were 0.78 million in 1978 and 1.2 in 2009 (reaching 1.5 in 2019). Workers employed in 'financial and insurance activities' also increased from 0.8 million in 1978 to 1.1 in 1990, remaining stable around that number ever since. This trend has fostered the demand for university graduates and led to an increase in wages for individuals with higher education because, for instance, as Brown (1995) and Bynner (1998) argue, modern companies' skill requirements (flexibility, working in a team, creativity) are exactly the kind of skills that tertiary education provides. In such contexts, there was a rapid and unprecedented increase in participation rates in higher education among young people. According to the Dearing Report of the National Committee of Inquiry into Higher Education, enrolment in higher education rose from 3.4 per cent in 1950 to 8.4 per cent in 1970, 19.3 per cent in 1990 and 33 per cent in 2000 in England and Wales, and reached about 50 per cent in Scotland and Northern Ireland (Clark, 2006).

However, this remarkable increase in the supply of young graduates to the labour market did not catch up with the demand in the labour market (Higher Education Funding Council for England, 2001), which still outstripped the supply, making higher educational qualifications still offer payoffs in economic terms (Blundell et al., 2004). In fact, according to the ONS, average earnings of workers employed in 'financial and insurance', 'real estate', 'professional, scientific and technical activities' and 'administrative and support activities' increased between 2001 and 2009

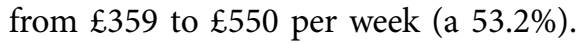

In this context, the relatively low number of seniors who at the time had higher education (1.1 million between 50 and 74 years of age in 1994 and 2.4 million in 2008, according to Eurostat ${ }^{2}$ ) found themselves in an advantageous position. Because of the restructuring of companies along hierarchical lines, there was a dramatic increase in demand for new qualification profiles (Snower, 1999), which only workers with tertiary education and solid work experience could satisfy.

By contrast, senior workers with low levels of professional qualifications became increasingly redundant. Since retraining a worker with only a few years of working life before retirement can be perceived as less efficient than hiring a young worker, employability of senior workers might suffer in comparison to that of younger job applicants (Alderson, 1999; Lain et al., 2019; Phillipson, 2019). Speed of technological change initiated during the 1990s may have contributed to the spread of the already-existing ageist attitudes in relation to perceptions of older workers' productivity (Loretto et al., 2000; Martin et al., 2014). In a survey conducted in 2005, British employers reported the expected consequences, giving an eventual 
'ageing personnel structure for own organisation'. Although 78 per cent would expect an 'increase in know-how and experience', only 25 per cent replied they expected an 'increase in productivity', 42 per cent would expect an increase in labour costs' and 45 per cent reported to expect 'greater resistance to change' (Van Dalen et al., 2009). Various ways of mismanagement of age composition and age relations within private organisations have been described (Brooke and Taylor, 2005) and there is, in fact, an extensive literature on how stereotypes relating to older workers' productivity may be affecting the proper functioning of the labour market (Harris et al., 2018).

\section{Demographic ageing and pension reforms}

The British pension system followed Beveridgean social policy, which is characterised by universal provision of benefits, entitlement based on residence and need, with flat-rate benefits and financing through general taxation. The Beveridge pension system has two tiers of provision (plus the third voluntary tier provisions: savings and insurances). The first tier is publicly provided tax-financed pensions and is aimed at low earners. This pension is unrelated to earnings and makes up only 15 per cent (in 2002) of average male earnings (Disney et al., 2003).

Private pensions (the second tier) include occupational pensions and individual retirement accounts, known in the UK as personal pensions (Blundell et al., 2002). Occupational pensions are the most important income source in later life. According to the ONS, the number of pensioners receiving occupational pensions rose from 7 million workers in 1991 to 8.5 million in 2007 (10.2 million in 2018). Lower earners are less likely than higher earners to be part of an occupational pension scheme, and are also less likely to have any kind of private pension arrangements (Blundell and Johnson, 1999). On the contrary, lower earners are more likely to be part of SERPS.

In the 1980s, the Conservative British Government of Margaret Thatcher promoted the expansion of private pensions so they would become the dominant form of pension provision for the whole population and not just for higher earners (Taylor-Gooby, 2006). There were significant cutbacks in state pensions and widespread deregulation of the private sector. The tax imposed to pension fund surpluses implemented by the Chancellor of the Exchequer Nigel Lawson in 1988 played a particularly important role. Although such measures tended to incline companies to reduce their contributions to pension fund reserves, the booming stock market of the time led to increased pension funds' surpluses (Walker and Foster, 2006). Similar policies were adopted during the Labour Government formed in 1997 (Evandrou and Falkingham, 2009), when the abolishment of tax relief on dividends from pension funds' investments was approved by Chancellor Gordon Brown of Tony Blair's Government.

In this context, defined contribution (DC) pension schemes (personal or stakeholder pensions) became generalised and many employees switched from defined benefit (DB) to DC provisions. Up to 6 million employees had left SERPS by 1998 (Walker, 1999). A few years later, DC plans already covered more than one-third of employees with private pensions (Banks and Blundell, 2005; Banks and Smith, 2006).

Justification for such policies stems from increasing concern about the impact of demographic ageing on the cost of SERPS and the intention to reduce the projected 
public pension expenditure (Disney et al., 2003). Liberal ideology, emphasising the importance of individual responsibility to provide financially for old age, also contributed to justifying the marketisation of the pensions system in the UK (Walker and Foster, 2006: 444). Lain (2016) identifies a change in the logic regulating retirement in the UK, from paternalism to self-reliance, seeking to encourage employment beyond the age of 65 when sufficient pension income was not secured.

However, the UK displays relatively high employment rates among its senior population and the lowest expenditure for their pension system when compared with other European countries (Mann, 2007). Moreover, ageing is not increasing as fast in the UK as in other countries, and the UK has relatively high employment ratios among its senior population (Falkingham, 1989). Given these considerations, many have questioned the necessity of such reforms, which transferred risks from employers to employees and left those with lower incomes inadequately protected against poverty in old age (Cesaratto, 2006a, 2006b; Walker and Foster, 2006: 435). Evidence of substantial miss-selling of private pensions to workers who should have remained in SERPS (Budd and Campbell, 1998; Georgosouli, 2014) fuelled the controversy.

\section{The gender gap(s)}

Women's labour market participation has increased dramatically since the 1980s. According to Eurostat, the number of women older than 50 employed in the UK increased from 2.2 million in 1990 to 3.5 million in 2008 (4.8 million in 2018).

Employed women between 50 and 74 years of age with 'higher education' increased from 18 to 31 per cent between 1995 and 2008. Senior workers with 'less than primary', 'primary' and 'lower secondary' education decreased from 61 to 32 per cent among women between 1995 and 2008.

However, the increasing participation of women in the labour market and the substantial increase in the number of women with tertiary education were accompanied by other trends that contributed to consolidating a pay gap between men and women. For instance, data from the ONS on employment by type of industry reveal a strong segmentation by gender. Women are overrepresented in industries where salaries are lower, like 'Education' or 'Human health and social work activities'. The percentage of women employed in 'Education' rose from 12 per cent in 1997 to 15 per cent in 2007 (and to 16\% in 2019), while the percentage of men in 'Education' remained stable at around 5-6 per cent. Male employment in the 'Health and social work' sector rose from 3.7 per cent in 1997 to 4.5 in 2007 (and to 5.8\% in 2019). Among women, the share of those employed in 'Health and social work activities' rose from 19.5 per cent in 1997 to 20.5 per cent in 2007 (and to 22\% in 2019). During the same periods, the share of men employed in the public sector decreased from 16.2 per cent in 1997 to 15.2 per cent in 2007 (and to 14.0\% in 2019), while the share of women employed in the public sector remained stable at around 30-33 per cent.

Labour income in late life and pension income depend on a variety of characteristics and circumstances besides education and branch of industry. Seniority within the company and occupation are often very important determinants of income in late life, particularly among those employed in firms and occupations where promotions and raises are common after a certain age. The number of years spent 
working and the question of whether the firm provides a private pension scheme (generally a DC scheme) are also very important determinants of pension income (Sefton et al., 2011). All these elements operate in a way that produces staggering gap(s) between men and women in late-life income. From a lifecourse perspective, women tend to change employers, work part-time or on contracts of limited duration, and experience career breaks for family-related issues (such as child care) more often than men, which results in fewer years spent in paid full-time work (Ginn and Arber, 1991, 2001). Some comparative studies have shown that the gender gap in late-life income is, indeed, particularly high in the UK (Harkness and Waldfogel, 2003).

According to Eurostat, in 2006, the average number of years spent working among non-employed persons (mainly retired) was 42.4 for men and 33.1 for women. Data segmented by occupation show that even among 'managers, professionals and technicians', the gap between men and women was substantial: 41.2 years for men and 32.8 for women.

Greater discontinuities in paid employment over working life also affect women's income in late life. For instance, men receive a premium during their middle years that is not observed for women (Rake et al., 2000: 304). According to Eurostat, the gender pay gap in 2008 was estimated to be 9.1 per cent for workers aged 25-34, 23.9 per cent for workers aged $35-44$, up to 29.5 per cent for workers aged 45-54 and 22.5 per cent for workers aged 55-64.

Another factor that reinforced the pay gap between men and women was the occupational sex segregation of the labour market, particularly the feminisation of certain activities associated with low pay and unstable types of contracts (Blackwell, 2001; Browne, 2006). Occupational segmentation occurs not only within activities associated with low-skill profiles, but also within sectors where higher education is required. For instance, in 2008, in activities such as finance and insurance, the gender pay gap was 40.7 per cent, within the sector comprising professional, scientific and technical activities it was 32.2 per cent, within the health and social work sector it was 30 per cent, and among those employed in the wholesale and retail trade it was 27.3 per cent (Eurostat).

Lower salaries during working life, particularly during middle-age years, along with employment discontinuities translated into lower pension income for women. Pension reforms reinforced this because they were designed for a life of continuous full-time employment, typical of upper- and middle-class men (Ginn and Arber, 1993, 1998). The change in indexation of the basic state pension from earnings to prices in 1982 devalued the basic pension compared to average earnings (about 6\% between 1980 and 2002). Reforms to SERPS in 1986 and 1995 reduced pension wealth from 25 per cent of the best 20 years to 20 per cent of the best 40 years of contribution, which hit women hardest (Disney and Emmerson, 2005). Additionally, in 1995, under the John Major Government, it was announced that the retirement age for women would rise from 60 to 65, in line with that of men. Moreover, during the 1990s, women were twice as likely as men to be employed in smaller firms without occupational pension schemes or under types of contracts that limit access to the best pension schemes, and they were more likely to leave companies' schemes before reaching retirement age. Thus, pension reforms led to the increased vulnerability of women after retirement (Foster, 2011). 


\section{Hypotheses}

There is an academic and political debate about how economic growth impacts on income inequality that began more than half a century ago (Kuznets, 1955). Statistical relationship can vary between countries and in many cases a positive association between economic growth and inequality has been identified (Lundberg and Squire, 2003; Yang et al., 2021). When inequality increases during a period of marked economic growth, it is often hard to assess if the reason is that only individuals of the highest income levels are gaining while the incomes of the rest are stagnating or if incomes of those with the highest income levels are simply growing faster than the incomes of the rest. Moreover, there are works pointing out that while inequalities may be an inherent part of the dynamism of capitalism, certain policies can contribute to accentuate it even further (Sherman and Sherman, 2018).

Our work deals directly with these controversies, posing the question of how the booming economic cycle experienced by the British economy between 1991 and 2007 has affected late-life income of workers and pensioners. Our assumption is that inequalities between certain profiles of workers and retirees have grown across the cohorts. Based on historical background, we hypothesise that less-skilled senior workers have seen their wages and pension incomes stagnate while the highly educated have benefited from major income gains. The combined effect of these trends contributed to an increasing income gap between the highly educated and the less skilled. Institutional reforms of the pension system may have exacerbated such inequalities among retirees even further.

This historical period of economic growth was also characterised by increasing participation in the British labour force of women of 50 years of age and older. Given that rewards from higher education are unlikely to suffice to offset the drawbacks of strong labour market segmentation and career discontinuities among women, we expect that inequalities between highly educated and less-skilled women have not increased as much as among men. That should result into an increasing gender gap(s) in wages and pension income between highly educated female workers and retirees and their male counterparts.

We hypothesise increasing inequalities between senior workers depending on their educational attainment. We argue that low-qualified older workers have suffered a disproportionate impact of the demand shift in the labour market (Golsch et al., 2006), while higher-educated workers actually benefited from the new possibilities brought about by the expansion of the knowledge-service sector.

\section{Income from work in late life}

Previous studies report increasing differences in earnings according to the level of education (Banks et al., 2002). Such trends may be caused by decreasing salaries of low-skilled workers, increasing returns to highly educated workers or both at the same time. Therefore, for highly educated workers we expect an increase in returns from work in late life when younger and older cohorts are compared (Hypothesis H1a). For low-qualified workers we expect stagnation or even a decrease in returns from work in late life across the cohorts (H1b). However, H1a may not necessarily 
apply to women with tertiary education since highly educated senior women are more likely to be employed in the public sector, where income increases have not been as salient as in the high-service private sector.

\section{Pension income}

We believe that because of the nature of pension reforms, increasing labour income inequalities should translate into increasing pension income inequalities. Given that a greater number of higher earners than lower earners have contracted out from state into private pensions, we expect that the gap in pension income between workers with low educational attainment and those with high educational attainment widened across the cohorts. Thus, we expect that pension provisions for highly educated males of younger cohorts have increased compared to highly educated males of the older cohorts (Hypothesis H2a), while they have stagnated or even decreased if comparing younger and older cohorts of low-skilled workers (H2b).

Insofar as highly educated women have not benefited to the same extent as their male counterparts from higher income in late life, and as pension reform severely penalises career discontinuities, H2a may not apply to highly educated women. Thus, differences in pension provisions between women with different levels of educational attainment should not have increased significantly across the cohorts.

\section{Data and methods}

The data used in this study are from the BHPS, collected by the Institute for Social and Economic Research (ISER) at the University of Essex since September 1991, which provides information on education, income and detailed data on individual characteristics. Additionally, retrospective data help reconstruct the employment histories of individuals. The BHPS represents a national sample of households, including about 10,000 persons in approximately 5,500 households. Households in Northern Ireland and the North and West Highlands were excluded from the survey.

\section{Working and pension income}

The analysis for working income is based on 1,169 workers aged 50 who were in dependent employment within the research window (1991-2007). The starting point for pension income models, based on 1,240 cases, is the first year receiving work-related pension income and working less than 12 hours per week. Working income and pension income models are estimated using linear mixed random-effect models (LMM). Because of the right-skewed distribution for working income models, we use log gross hourly wages. For pension income models, we use monthly pension income reported yearly at the time of the interview. LMM are an appropriate method for treating Gaussian repeated correlated outcomes (Molenberghs and Verbeke, 2005). Both models deal with unbalanced data: data for working income models cover an average of six years and data for pension income models cover on average five years. For the intercept and slope models 
with incorporated covariates and the $i$ th subject at the $j$ th measurement occasion and depending on the $p$ th covariate, we use the following notation:

$$
\begin{aligned}
Y_{i j}= & \left(\beta_{00}+\beta_{01} x_{i j 1}+\beta_{02} x_{i j 2}+\ldots+\beta_{0 p} x_{i j p}+b_{0 i}\right) \\
& +\left(\left(\beta_{10}+\beta_{11} x_{i j 1}+\beta_{12} x_{i j 2}+\ldots+\beta x_{i j p}+b_{1 i}\right) \times \text { Time }_{i j}\right)+\epsilon_{i j}
\end{aligned}
$$

The first part of Equation 1 with intercept $\beta_{00}$ and corresponding covariates $\beta_{0 p} x_{i j p}$ stands for the outcome of starting position (income at age 50 and pension at time of retirement). The second part of the equation with slope $\beta_{10}$ and corresponding covariates $\beta_{1 p} x_{i j p}$ reflects the outcomes of the change in the outcome variable (income growth and pension growth). Random intercepts $b_{01}$ and random slope $b_{11}$ effects are assumed to be normally distributed with mean 0 , variances $\delta_{0}, \delta_{1}$, covariance $\delta_{01}$ and will be introduced if they improve the model fit. Since we have unbalanced data, we use a $2 \times 2$ unstructured covariance matrix. Measurement error $\epsilon_{i j}$ is assumed to be independent of random effects $b_{0 i}$ and $b_{1 i}$ and normally distributed. Note that variable time $_{i j}$ is in months: at the start of a process (at age 50 or at the time of retirement) the variable time is set to zero and following time-points (time of interview) correspond to months elapsed since the start of the process (at age 50 for income models and time of retirement for pension income models).

\section{Covariates}

Because we are interested in how flexibilisation of the labour market (Stone, 2006) affects pension income and contributes to widening the gender gap (Coyle, 2005), the following variables referring to late working life were used in our models: number of employer changes, cumulative unemployment and labour market inactivity experience, and contributions paid into pension schemes. In addition to the covariates described earlier, we included (a) race (white $=1$ ), (b) marital status, (c) employment status of the partner, (d) regions (four regions created from 12 official regions: North, South, Middle, Scotland) and (c) health (bad =1). For the analysis of labour income, we added the following covariates: (a) duration in inactivity ${ }^{3}$ and in unemployment since the age of 50, (b) regional unemployment rate (separate for men and women), (c) branch of industry (based on a modified Singelmann, 1978 classification by collapsing transformative and distributive industries, and personal service and producer service industries), (d) change of employer since age 50 (as dummy), (e) full-time versus part-time employment, (f) permanent versus temporary contract, (g) firm size and (h) the year at age 50. For the analysis on pension income we included a different list of covariates: (a) number of employer changes since 1978, (b) permanent contract in the last job, (c) full-time position in the last job, (d) cumulative duration in inactivity (same definition as for labour income), unemployment and family-related care over the working lifespan, and (e) cohort metric (= year of retirement).

Our educational variables are based on the Comparative Analysis of Social Mobility in Industrial Nations classifications provided in the BHPS, also known as the CASMIN scale (Brauns and Steinmann, 1997). Due to the low numbers of cases available for some educational groups, we collapsed the CASMIN classification 
into five categories: I - primary education (= inadequately completed elementary education or completed compulsory education without vocational qualification) ${ }^{4}$; II - primary education with vocational qualification; III - O-level or equivalent (intermediate general qualifications without vocational training or intermediate vocational qualification); IV - A-level (general maturity certificate with or without vocational training); and V-tertiary education (lower and higher tertiary education). These five categories were introduced as dummies in our models. To grasp the changes over cohorts, we used a variable Cohort metric and interacted it with variables for educational attainment. ${ }^{5}$

\section{Results}

To facilitate a better understanding of the results, broad summaries of descriptive statistics of the sub-sample used are provided in Tables 1 and 2.

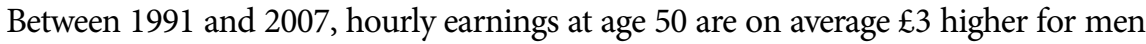
than for women. This can be partially explained by several factors: up to 18 per cent of men have tertiary education as opposed to only 12 per cent of women. Up to 37 per cent of women but only 27 per cent of men are employed in small firms at age 50 . This is relevant because in smaller firms, salaries tend to be lower and pension schemes less generous (Green et al., 1996; Belfield and Wei, 2004). Although no major differences are observed regarding types of contracts and the number of changes of employers, 98 per cent of men work full-time but only 82 per cent of women do so. The distribution of men and women across different branches of the economy is also quite diverse: 20 per cent of women are employed in the social and personal service sector and only 22 per cent in the extractive or transformative industries. Among senior men, only 11 per cent work in the personal service sector and up to 48 per cent in the extractive and transformative industries. These results relate to data from Eurostat shown in previous sections, revealing the unequal distribution of male and female workers in different industries and occupations, and how salient salary gaps between men and women are even within each industry and occupation.

Table 2 shows that the average pension income between 1991 and 2007 is more than twice as high for men than for women (statistically significant) despite the age of retirement being virtually the same (63.7 years for women and 65 for men). This gap can be partly explained by differences in (a) educational attainment ( $45 \%$ of retired women but only $36 \%$ of retired men have only primary education), (b) parttime employment (up to $81 \%$ of men but only $47 \%$ of women held a full-time job before retirement), and (c) time spent in taking care of another family member, which, in the British context, has a salient scarring effect on old-age income (Dewilde, 2012). These differences are in line with data shown in previous sections indicating strong gender labour market segmentation and a higher incidence of job discontinuity (particularly related to family and care-related activities) and part-time employment among women.

\section{Labour income in late life}

In accordance with human capital expectations, the hourly working income at age 50 clearly corresponds to educational attainment (Table 3, Model 1): in comparison 
Table 1. Descriptive statistics for observed women and men at age 50

\begin{tabular}{|c|c|c|c|c|}
\hline & \multicolumn{2}{|c|}{ Women } & \multicolumn{2}{|c|}{ Men } \\
\hline & Mean & SD & Mean & SD \\
\hline Hourly earnings $(£)$ & 7.08 & 4.73 & $10.08^{\star \star}$ & 5.54 \\
\hline Cohort metric (year of retirement) & 2001.39 & 4.27 & 2001.10 & 4.99 \\
\hline \multicolumn{5}{|l|}{ Region: } \\
\hline South & 0.41 & 0.49 & 0.39 & 0.49 \\
\hline Middle & 0.25 & 0.43 & 0.28 & 0.45 \\
\hline North & 0.26 & 0.44 & 0.26 & 0.44 \\
\hline Scotland & 0.08 & 0.28 & 0.07 & 0.26 \\
\hline $\begin{array}{l}\text { Primary education without vocational } \\
\text { qualification }\end{array}$ & 0.21 & 0.41 & $0.17 \dagger$ & 0.37 \\
\hline Primary education with vocational qualification & 0.16 & 0.37 & 0.15 & 0.36 \\
\hline O-level ${ }^{1}$ & 0.32 & 0.47 & $0.20^{\star \star}$ & 0.4 \\
\hline A-level ${ }^{1}$ & 0.19 & 0.39 & $0.30^{\star \star}$ & 0.46 \\
\hline Tertiary education & 0.12 & 0.33 & $0.18^{\star \star}$ & 0.38 \\
\hline \multicolumn{5}{|l|}{ Firm size: } \\
\hline $1-24$ & 0.37 & 0.48 & $0.27^{\star \star}$ & 0.44 \\
\hline $24-200$ & 0.39 & 0.49 & 0.35 & 0.48 \\
\hline $200-1,000$ & 0.15 & 0.35 & $0.27^{\star \star}$ & 0.44 \\
\hline 1,000 and more & 0.09 & 0.29 & 0.12 & 0.32 \\
\hline Extractive industry & 0.04 & 0.2 & $0.20^{\star \star}$ & 0.4 \\
\hline Transformative industry & 0.18 & 0.39 & $0.28^{\star \star}$ & 0.45 \\
\hline Distributive industry & 0.25 & 0.43 & $0.31^{*}$ & 0.46 \\
\hline Production service & 0.32 & 0.47 & $0.10^{\star \star}$ & 0.3 \\
\hline Social and personal service & 0.20 & 0.4 & $0.11^{\star \star}$ & 0.31 \\
\hline Permanent contract at retirement & 0.94 & 0.24 & 0.95 & 0.22 \\
\hline Full-time job at retirement & 0.82 & 0.38 & $0.98^{\star \star}$ & 0.15 \\
\hline Change of employer (as dummy) & 1.01 & 1.45 & 1.04 & 1.44 \\
\hline Duration of inactivity (months) 2,3 & 0.51 & 3.21 & $0.25 \dagger$ & 1.6 \\
\hline Duration of unemployment (months) & 0.46 & 2.61 & $0.91^{\star}$ & 3.76 \\
\hline Health (Ref. Bad) & 0.89 & 0.31 & $0.92 \dagger$ & 0.27 \\
\hline White & 0.97 & 0.18 & 0.98 & 0.15 \\
\hline Married & 0.74 & 0.44 & $0.82^{\star \star}$ & 0.39 \\
\hline Spouse in job & 0.56 & 0.5 & $0.61 \dagger$ & 0.49 \\
\hline Unemployment rate (\%) & 3.38 & 1.15 & $4.00^{\star \star}$ & 1.82 \\
\hline
\end{tabular}


Table 1. (Continued.)

\begin{tabular}{lcccc}
\hline & \multicolumn{2}{c}{ Women } & & \multicolumn{2}{c}{ Men } \\
\cline { 2 - 3 } & Mean & SD & Mean & SD \\
\hline Observations & & 637 & & 532 \\
\hline
\end{tabular}

Notes: SD: standard deviation. Ref.: reference category. 1. O-level: intermediate general qualifications without vocational training or intermediate vocational qualification. A-level: general maturity certificate with or without vocational training. 2. Average duration spent in each given state of inactivity or unemployment since the age of 50.3 . Individuals reporting retirement without reporting any sources of pension income are considered as inactive. Additionally, those who report of being sick or disabled or reporting 'other' states are also defined as 'inactive'.

Source: British Household Panel Survey (1992-2007).

Significance levels: $\dagger p<0.1,{ }^{\star} p<0.05,{ }^{\star \star} p<0.01$ ( $t$-test for differences between men and women).

to individuals with tertiary education, those with low educational attainment have a lower income at age 50 (see the Education variables: $\beta_{0}$ education $x_{i j \text { education }}$ ).

To investigate the changes across cohorts, we introduced the variable Cohort metric (Table 3, Model 1). Both male and female workers experienced statistically significant income growth at age 50 over cohorts (see Cohort metric). To capture changes over cohorts for different educational groups and test our hypotheses we interacted the variable Cohort metric with dummy variables for educational attainment (Model 2). Women in all educational groups (except Group IV, A-level) saw wage increases across the cohorts between 1991 and 2007, the observation window of our research; we therefore do not find an increasing gap in wages at age 50 among

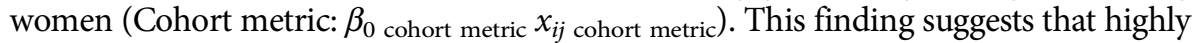
educated women did not profit from their higher educational level across the cohorts. In contrast, the increase of income over cohorts for men (Cohort metric) is mainly driven by those with tertiary education, which completely supports H1a. Income of individuals with other educational attainment stagnates between 1991 and 2007 (though the results are not significant for those in Group III, O-level). These results are in line with $\mathrm{H} 1 \mathrm{~b}$ and may reflect devaluation of their skill profiles (Cohort metric + Cohort metric $\times$ Educational achievement) ${ }^{6}$

Comparing variations in income growth after age 50 among educational groups, most educational groups without tertiary education (see figures for Education $\times$ Time: $\beta_{1}$ education $x_{i j \text { education }} \times$ Time $)$ perform worse than those with tertiary education, the reference category (though results are not significant for female workers in Group IV, A-level, and for male workers in Groups I and II, with primary education, with or without vocational training). Keeping in mind that income growth occurs especially in the beginning and middle of working life (Rubinstein and Weiss, 2006), it is striking that the highly educated workers experience income growth even late in their career (Time in Model 1). Those low-qualified workers who have especially low attachment to the labour market are also more likely to drop from it and not to return to the labour market. Therefore, such selection might bias results for low-qualified workers when comparing income growth for workers holding primary and tertiary degrees. Concerning the changes over cohorts, there are no differences in income growth between the education groups (results not shown). 
Table 2. Descriptive statistics for women and men observed at time of retirement

\begin{tabular}{|c|c|c|c|c|}
\hline & \multicolumn{2}{|c|}{ Women } & \multicolumn{2}{|c|}{ Men } \\
\hline & Mean & SD & Mean & SD \\
\hline Sum of pension income $(£)$ & 322.61 & 280.84 & $778.41^{\star \star}$ & 488.35 \\
\hline Age at retirement & 63.70 & 4.68 & $65.00^{\star *}$ & 5.46 \\
\hline Cohort metric (year of retirement) & 1999.33 & 4.22 & 1998.86 & 4.22 \\
\hline Employer pension scheme (DB or DC) & 0.29 & 0.45 & $0.47^{\star \star}$ & 0.50 \\
\hline Private personal pension (second tier) & 0.20 & 0.40 & $0.29 * *$ & 0.45 \\
\hline Additional contributions & 0.09 & 0.29 & $0.13^{\star}$ & 0.34 \\
\hline \multicolumn{5}{|l|}{ Region: } \\
\hline South & 0.36 & 0.48 & 0.35 & 0.47 \\
\hline Middle & 0.28 & 0.45 & 0.29 & 0.45 \\
\hline North & 0.27 & 0.44 & 0.28 & 0.45 \\
\hline Scotland & 0.09 & 0.28 & 0.08 & 0.27 \\
\hline $\begin{array}{l}\text { Primary education without vocational } \\
\text { qualification }\end{array}$ & 0.45 & 0.50 & $0.36^{\star *}$ & 0.48 \\
\hline $\begin{array}{l}\text { Primary education with vocational } \\
\text { qualification }\end{array}$ & 0.12 & 0.33 & 0.15 & 0.36 \\
\hline O-level ${ }^{1}$ & 0.22 & 0.42 & 0.22 & 0.41 \\
\hline A-level ${ }^{1}$ & 0.15 & 0.36 & $0.19 \dagger$ & 0.39 \\
\hline Tertiary education & 0.05 & 0.22 & 0.08 & 0.27 \\
\hline Changes of employer since 1978 & 2.18 & 2.72 & 1.95 & 2.44 \\
\hline Permanent contract at age of retirement & 0.76 & 0.41 & $0.72 \dagger$ & 0.44 \\
\hline Full-time contract at age of retirement & 0.47 & 0.49 & $0.81^{\star \star}$ & 0.36 \\
\hline Self-employed at age of retirement & 0.09 & 0.28 & $0.17^{\star \star}$ & 0.37 \\
\hline \multicolumn{5}{|l|}{ Duration (in months) before retirement for: } \\
\hline Inactivity $^{2}$ & 31.12 & 65.50 & $40.62^{\star}$ & 65.25 \\
\hline Time taking care of another family member & 149.72 & 140.84 & $0.86^{\star \star}$ & 9.64 \\
\hline Unemployment & 5.09 & 23.59 & 14.16 & 35.97 \\
\hline Health (good) & 0.87 & 0.26 & $0.84 \dagger$ & 0.30 \\
\hline White & 0.98 & 0.13 & 0.97 & 0.17 \\
\hline Married & 0.69 & 0.45 & $0.79^{\star \star}$ & 0.40 \\
\hline Observations & \multicolumn{2}{|c|}{709} & \multicolumn{2}{|c|}{531} \\
\hline
\end{tabular}

Notes: SD: standard deviation. DB: defined benefit. DC: defined contribution. 1. O-level: intermediate general qualifications without vocational training or intermediate vocational qualification. A-level: general maturity certificate with or without vocational training. 2. Individuals reporting retirement without reporting any sources of pension income are considered as inactive. Additionally, those who report of being sick or disabled or reporting 'other' states are also defined as 'inactive'.

Source: British Household Panel Survey (1992-2007).

Significance levels: $\dagger p<0.1,{ }^{\star} p<0.05,{ }^{\star \star} p<0.01$ ( $t$-test for differences between men and women). 
Table 3. Income growth for women and men starting at age 50 (linear mixed random-effect models: log of hourly wages) ${ }^{1}$

\begin{tabular}{|c|c|c|c|c|}
\hline & \multicolumn{2}{|c|}{ Women } & \multicolumn{2}{|c|}{ Men } \\
\hline & Model 1 & Model 2 & Model 1 & Model 2 \\
\hline \multicolumn{5}{|l|}{ Income at age 50: } \\
\hline \multicolumn{5}{|l|}{ Education (Ref. Tertiary): } \\
\hline $\begin{array}{l}\text { Primary without vocational } \\
\text { qualification }\end{array}$ & $-0.63^{\star \star \star}$ & $-0.69^{\star \star \star}$ & $-0.61^{\star \star \star}$ & $-0.37^{\star \star \star}$ \\
\hline Primary with vocational qualification & $-0.52^{\star \star \star}$ & $-0.57^{\star \star \star}$ & $-0.49^{\star \star \star}$ & $-0.30^{\star \star \star}$ \\
\hline O-level & $-0.40^{\star \star \star}$ & $-0.49^{\star \star \star}$ & $-0.30^{\star \star \star}$ & $-0.19^{\star \star}$ \\
\hline A-level & $-0.24^{\star \star \star}$ & $-0.14^{\star}$ & $-0.21^{\star \star \star}$ & -0.06 \\
\hline Cohort metric & $0.03^{\star \star \star}$ & $0.04^{\star \star \star}$ & $0.02^{\star \star \star}$ & $0.04^{\star \star \star}$ \\
\hline \multicolumn{5}{|l|}{ Cohort $\times$ Education (Ref. Tertiary): } \\
\hline $\begin{array}{l}\text { Primary without vocational } \\
\text { qualification }\end{array}$ & & 0.01 & & $-0.03^{\star \star \star}$ \\
\hline Primary with vocational qualification & & 0.00 & & $-0.02^{\star \star \star}$ \\
\hline O-level & & 0.01 & & -0.01 \\
\hline A-level & & $-0.02^{\star}$ & & $-0.02^{\star \star}$ \\
\hline Employer change & & $-0.02^{\star}$ & & $-0.03^{\star \star \star}$ \\
\hline Incidence of unemployment & & -0.01 & & $-0.43^{\star \star \star}$ \\
\hline \multicolumn{5}{|l|}{$\begin{array}{l}\text { Unemployment } \times \text { Education } \\
\text { (Ref. Tertiary): }\end{array}$} \\
\hline $\begin{array}{l}\text { Primary without vocational } \\
\text { qualification }\end{array}$ & & 0.03 & & $0.35^{\star \star \star}$ \\
\hline Primary with vocational qualification & & 0.03 & & $0.31^{\star}$ \\
\hline O-level & & -0.06 & & $0.36^{\star \star \star}$ \\
\hline A-level & & 0.10 & & $0.22^{\star}$ \\
\hline Constant & $1.89^{\star \star \star}$ & $1.84^{\star \star \star}$ & $2.27^{\star \star \star}$ & $2.28^{\star \star \star}$ \\
\hline \multicolumn{5}{|l|}{ Income growth: } \\
\hline \multicolumn{5}{|l|}{ Education $\times$ Time $($ Ref. Tertiary) $\times 100$ : } \\
\hline $\begin{array}{l}\text { Primary without vocational } \\
\text { qualification }\end{array}$ & $-0.11^{\star}$ & $-0.10^{*}$ & -0.03 & -0.05 \\
\hline Primary with vocational qualification & $-0.19^{\star \star \star}$ & $-0.19^{\star \star \star}$ & -0.06 & -0.08 \\
\hline O-level & $-0.17^{\star \star}$ & $-0.16^{\star \star \star}$ & $-0.13^{\star}$ & $-0.15^{\star \star}$ \\
\hline A-level & -0.09 & -0.09 & $-0.12^{\star \star}$ & $-0.14^{\star \star}$ \\
\hline Time (=tertiary education) $\times 100$ & $0.38^{\star \star \star}$ & $0.38^{\star \star \star}$ & $0.24^{\star \star}$ & $0.25^{\star \star \star}$ \\
\hline
\end{tabular}


Table 3. (Continued.)

\begin{tabular}{lcccccc}
\hline & \multicolumn{2}{c}{ Women } & & \multicolumn{2}{c}{ Men } \\
\cline { 2 - 3 } \cline { 7 - 7 } & Model 1 & & Model 2 & & Model 1 & Model 2 \\
\hline Number of subjects & 637 & 637 & & 532 & 532 \\
\cline { 7 - 8 } Number of cases & 4,338 & 4,338 & & 3,632 & 3,632 \\
\hline
\end{tabular}

Notes: Ref.: reference category. 1. Full set of variables: dummies for branch of industry, regional unemployment rate, dummy variables for regions, dummy for full-time contract, dummy for permanent contract, dummies for firm size, dummy for married, dummy for spouse in job and dummy for white. Model 1: main model for working income at age 50 and subsequent income growth by educational groups. Additionally, the variable Cohort metric captures average change for educational groups over cohorts. Controls for variables in Note 1 are included in the model. Model 2: includes variables in Model 1 plus changes of working income at age 50 over cohorts by educational groups and control for employer change. Additionally we also control for duration of unemployment and duration of inactivity (results not shown, not statistically significant).

Source: British Household Panel Survey (1992-2007).

Significance levels: ${ }^{\star} p<0.05,{ }^{\star \star} p<0.01,{ }^{\star \star \star} p<0.001$.

In the next step, we analysed the impact of unemployment. Men with the highest education (tertiary) suffer the most severe income losses after unemployment (Model 3), which corresponds to previous research (Arulampalam et al., 2001; Gregory and Jukes, 2001). Good job matches are associated with rising tenure. Given that highly educated workers (managers and professionals) achieve the best job matches at the end of their employment career, a disruption of the good matches is penalised by income loss (Gregory and Jukes, 2001). However, one should keep in mind that unemployment is a very unusual occurrence for highly educated people and lasts only a short time.

\section{Pension income}

As shown in Table 4 (Model 1), pension income is clearly structured by education. First, all educational groups receive lower pensions - though results are not significant for female workers with A-levels - at the point of retirement compared to workers with tertiary education (see Education variables: $\beta_{0}$ education $x_{i j \text { education }}$ ). Second, in the following years, they also display lower pension income growth rates - although the results are not significant for males in Group III, O-level - than individuals with tertiary education (see variables in Time $\times$ Education: $\beta_{1}$ education $x_{i j}$ education $\times$ Time).

The average increase in pension income across the cohorts in the first year of

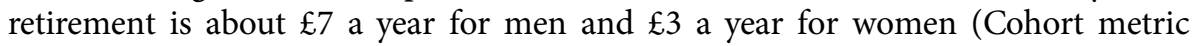
in Model 1 of Table 4). In order to demonstrate the changes over cohorts and give support to our hypotheses, we interacted the Cohort metric variable with educational attainment (Table 4, Model 2). When observing results for women of different educational groups, there is only scant (and not significant) evidence of an increasing gap in pension provisions across cohorts, which is consistent with our expectation that $\mathrm{H} 2 \mathrm{a}$ does not apply to them. Results for men, on the contrary, clearly demonstrate the widening gap between educational groups across cohorts (see variable Cohort $\times$ Education). These findings strongly support $\mathrm{H} 2 \mathrm{a}$ and $\mathrm{H} 2 \mathrm{~b}$. Compared to tertiary education, men holding all other levels of educational attainment lose between $£ 19$ and $£ 28$ a year when receiving their first pension income, 
Table 4. Pension growth after retirement for women and men (linear mixed random-effect models) ${ }^{1}$

\begin{tabular}{|c|c|c|c|c|c|c|}
\hline & \multicolumn{3}{|c|}{ Women } & \multicolumn{3}{|c|}{ Men } \\
\hline \multicolumn{7}{|l|}{ Pension at retirement: } \\
\hline \multicolumn{7}{|l|}{ Education (Ref. Tertiary): } \\
\hline Primary without vocational qualification & $-159.93^{\star \star \star}$ & -89.68 & -103.28 & $-403.31^{\star \star \star}$ & $-237.41^{\star \star \star}$ & $-213.97^{\star \star \star}$ \\
\hline A-level & -53.01 & -17.19 & -27.25 & $-145.96^{\star \star \star}$ & 71.93 & 77.21 \\
\hline Cohort metric & $2.91^{\star \star}$ & 6.23 & 5.12 & $6.54^{\star \star \star}$ & $27.77^{\star \star \star}$ & $29.07^{\star \star \star}$ \\
\hline \multicolumn{7}{|l|}{ Cohort × Education (Ref. Tertiary): } \\
\hline Primary without vocational qualification & & -7.28 & -5.09 & & $-18.90^{\star \star}$ & $-14.97^{\star}$ \\
\hline \multicolumn{7}{|l|}{ Duration of: } \\
\hline Inactivity & & & 0.07 & & & $-0.94^{\star \star \star}$ \\
\hline Family care & & & $-0.25^{\star \star \star}$ & & & -0.44 \\
\hline Unemployment & & & $-0.43^{*}$ & & & $-1.35^{\star * *}$ \\
\hline Number of employee changes & & & -0.76 & & & $-6.76^{\star \star}$ \\
\hline Constant & $215.55^{\star \star \star}$ & $170.42^{*}$ & 81.00 & $626.06^{\star \star *}$ & $443.98^{\star \star *}$ & $470.53^{\star \star \star}$ \\
\hline
\end{tabular}




\begin{tabular}{|c|c|c|c|c|c|c|}
\hline \multicolumn{7}{|l|}{ Time $\times$ Education (Ref. Tertiary): } \\
\hline Primary without vocational qualification & $-1.19^{\star \star \star}$ & -0.95 & -1.00 & $-1.05^{\star}$ & 0.46 & 0.47 \\
\hline Primary with vocational qualification & $-1.08^{\star \star}$ & -0.86 & -0.95 & $-1.36^{\star \star}$ & 0.96 & 0.87 \\
\hline O-level & $-1.37^{\star \star \star}$ & -0.53 & -0.55 & -0.60 & 0.95 & 0.92 \\
\hline A-level & $-0.99^{\star \star}$ & -0.51 & -0.68 & $-1.20^{\star}$ & 0.13 & 0.05 \\
\hline \multicolumn{7}{|l|}{ Time $\times$ Cohort $\times$ Education (Ref. Tertiary): } \\
\hline Primary without vocational qualification & & -0.06 & -0.04 & & $-0.33^{\star \star}$ & $-0.32^{\star \star}$ \\
\hline Primary with vocational qualification & & -0.04 & -0.02 & & $-0.51^{\star \star \star}$ & $-0.50^{\star \star \star}$ \\
\hline O-level & & -0.15 & -0.14 & & $-0.34^{\star \star}$ & $-0.32^{\star \star}$ \\
\hline A-level & & -0.09 & -0.07 & & $-0.27^{\star}$ & $-0.26^{\star}$ \\
\hline Time $\times$ Cohort (=tertiary education) & & 0.09 & 0.08 & & $0.35^{\star \star \star}$ & $0.34^{\star \star \star}$ \\
\hline Time & $2.03^{\star \star \star}$ & $1.55^{\star}$ & $1.67^{\star \star}$ & $2.67^{\star \star \star}$ & 1.09 & 1.25 \\
\hline Number of subjects & 755 & 755 & 755 & 563 & 563 & 563 \\
\hline Number of cases & 5,249 & 5,249 & 5,249 & 3,987 & 3,987 & 3,987 \\
\hline
\end{tabular}

Notes: Ref.: reference category. 1. Full set of variables: dummy for permanent contract (last job), dummy for full-time contract (last job), dummies for regions, age at retirement, cumulated experience in branches of industry, dummy for married, dummy for spouse in job and dummy for white. Model 1: main model for pension income at age 50 and for pension growth after retirement by educational groups. Additionally, the variable Cohort metric captures the average change for educational groups over cohorts. Controls for variables in Note 1 are included in the model. Model 2: includes variables in Model 1 plus changes of pension income at age 50 over cohorts by educational groups, changes of pension growth after retirement over cohorts by educational groups and a control for employment change. Model 3: includes variables in Model 2 plus control for duration in inactivity, family care and unemployment.

Source: British Household Panel Survey (1992-2007).

Significance levels: ${ }^{\star} p<0.05,{ }^{\star \star} p<0.01,{ }^{\star \star \star} p<0.001$. 
which amounts to about $£ 300$ for primary and about $£ 400$ for secondary education within the observation window (1991-2007).

This gap for men is driven by the increase in pension income within the observational window and amounts to about $£ 28$ a year (see variables Cohort metric) and $£ 448$ across cohorts $((2007-1991) \times £ 28)$. In contrast, for workers with educational attainment below tertiary, neither men nor women experienced pension increases across cohorts. ${ }^{7}$

In order to demonstrate the changes in pension income growth between cohorts between 1991 and 2007, the variable accounting for changes in pension income for educational groups $\left(x_{i j}\right.$ education $\times$ Time $)$ was interacted with the variable accounting for birth cohort $\left(x_{i j}\right.$ cohort metric). Only males with tertiary education gained in pensions compared to the previous cohorts: each younger cohort (on yearly basis) for each month in retirement gains about 35 pence (see variable Time $\times$ Cohort). To demonstrate the changes over cohorts (between the 1991 and 2007 cohorts), we predicted the accumulated pension income arising solely from the pension growth for five years after retirement. Predictions show that the increase in pension income for men with tertiary attainment in 2007 is $£ 300$ higher than for their counterparts in 1991, observed already five years after retirement. ${ }^{8}$ We explain the striking increase in pension income growth over cohorts for men with tertiary education in terms of increasing diversification of pension income sources. The more highly educated increasingly receive their pension income from several sources at different time-points, which explains the high growth over time: they are more likely to receive an occupational pension and to receive it from several different employers.

Since these inequalities might be traced back to disadvantageous career histories, we also introduced covariates for working histories, inactivity and unemployment. There are no substantial changes in our results (Table 4, Model 3).

\section{Summary and discussion}

In this paper, we posed the question of how macro-economic changes shifted the demand for specific skill profiles across age cohorts and what this implied for older workers in terms of employment and pension income before the Great Recession of 2008 began. We showed that low-educated workers endured a disproportionate burden from economic restructuring and market internationalisation. We also show how differences between men and women strongly mediate the effects of educational attainment, indicating that the advantages of higher education are less evident for women than for men.

\section{Summary of results}

Results support our expectations of increasing returns to late-life income from work for the highly educated (H1a) and the skill profile devaluation for those with less than tertiary education, suggesting that during the studied period of economic expansion, inequalities have risen across the cohorts between highly educated and less-skilled men.

Among women, no major changes over the cohorts were observed. This provides support to our expectation that H1a may not apply to highly educated women. 
According to this expectation, segmentation of the labour market, employment discontinuity, the gender pay gap and the higher incidence of part-time employment have penalised women with tertiary education to the extent that the advantages of higher education are not as significant as observed among men.

Concerning pension income, our main hypothesis of increasing inequalities was also confirmed for men: highly qualified men benefited from tremendous increases in income across the cohorts not only before the time of their retirement but also in their pension provisions later on (H2a). At the same time, there was a stagnation of pension income for low-qualified workers when comparing different cohorts of less-skilled workers (H2b).

The widening pension income gap between younger and older cohorts of retired men can be explained by the fact that low-educated workers are more likely to receive only state pensions (first or second tier) than the highly educated, and because non-state pensions grow much more quickly than state pensions. Furthermore, a wide variety of occupational pensions (second tier) contribute to widening the gaps between educational groups since pension schemes earned by the lower-educated workers provide less pension income than the schemes earned by better-educated individuals. ${ }^{9}$ This is partly because many low-educated people work in part-time jobs (mainly women) or are self-employed (mainly men), which also might reduce pension income later in life. Early retirement via occupational pension schemes might be also a less-attractive option because of penalties associated with early retirement, and because low-educated workers are usually offered occupational schemes with low replacement rates (Hansen, 2000). Moreover, the reforms changing actuarial formulas for public pensions and the shifting emphasis on to private pensions might have a negative impact on future pension income for low-educated people since these reforms were designed for male full-time workers contributing to pension systems without interruption.

The striking increase in pension income growth for those with tertiary education is most likely due to increasing diversification of pension income sources. Higher-educated male workers are more likely to receive an occupational pension and not from only one but from several different employers. Moreover, since 1988, higher-qualified workers are also more likely to contribute to DC pension schemes (personal or stakeholder pensions - third tier).

Such trends are not observed among women with tertiary education. We believe this is partly because, as Table 1 shows, women tend to be overrepresented in the 'social and personal services' sector of the economy. This sector comprises public employment (such as school teachers) and is less exposed to income growth in late life and to changes of pension system than the private sector. Eurostat statistics provide additional support for this. Women aged 50 and over employed in education, health, social work and personal services represented 35 per cent of the total women aged 50 and over employed in 1992 in the UK, and almost 50 per cent in 2008. Corresponding figures for men were 19 and 18 per cent, respectively (Eurostat).

Table 2 also shows that only 47 per cent of women from our sample had a fulltime contract at age of retirement, compared to 81 per cent of men. Additionally, women spent a much longer time on average on employment breaks because of time spent 'taking care of another family member'. Overall, women report an 
average of 185 months not employed at age of retirement while men report 55 months. Finally, our sample data also confirm that men are more likely than women to have employer's pensions plans (DB or DC) as well as individual pension plans (second tier).

Therefore, from a lifecourse perspective that takes into account not only occupational segregation and the associated income inequalities but also discontinuity in working life and the unequal prevalence of part-time employment, it is unsurprising that women, including the highly educated, have not profited as much as highly educated men from pension income growth.

\section{Final discussion}

Highly educated senior male workers have undoubtedly profited from the macroeconomic changes that took place between 1991 and 2007. The increase in working and pension income provides clear evidence of this trend. The influx of an increasing number of young workers with tertiary education, far from posing competition or triggering displacement of their senior counterparts in the workplace, may even have been to their advantage. The hiring of growing numbers of young, highly qualified employees increased the demand for middle- and high-rank supervisors with university degrees and working experience. This trend favoured the market value of highly educated senior workers and therefore pushed the salaries of a group of workers with an already relatively high reservation wage further upward. Increasing wages in late life made it possible for highly educated seniors to take advantage of the third tier of the pension system by investing in private pension plans offering quite generous returns. This advantageous situation may have enabled them to adjust the timing of their retirement in line with their desires and personal convenience. Although further research is needed to assess how the timing of retirement patterns of the highly qualified has been affected, some evidence already shows that, for instance, unretirement is more common among the better educated (Platts et al., 2019).

Low-qualified senior workers do not show major pension income losses but have been unable to keep up with the highly educated workers in terms of rising income during the period analysed. Thus, we believe that the shift in pension provisions towards private pension schemes puts low-qualified workers at a clear disadvantage and contributes to the increase of social inequalities. One should also keep in mind that the government's post-employment redistributive efforts are not able to compensate for the low pension income resulting from working life, and many older workers may face poverty in old age - particularly women. Indeed, the increasing participation of women in the labour market and the increasing numbers of women with higher education between 1991 and 2007 have not translated into a reduction in the gender income gap in late life. Segmentation of the labour market, career discontinuity and pension reforms have penalised women, including the highly educated.

Since the Great Recession of 2008 began, many changes have occurred. Eradication of the default retirement age, increasing pension ages, increasing pension freedom, automatic enrolment, gender equalisation and increasing 'bridging employment' should have contributed to reducing the income gap(s) in old age between the highly educated and the less skilled, on the one hand, and men and 
women, on the other. However, recent research points to existing evidence suggesting that the most vulnerable workers may not be profiting equally from those changes. Raising the State Pension Age from 60 to 65 for women may have caught many female workers 'off-guard', particularly the less skilled in financial literacy, who may not have adapted adequately to change (Foster and Heneghan, 2018; Holman et al., 2020). For some, bridging employment could be described as career progression or a new 'career stage', of partial or flexible retirement (Parry and Wilson, 2014). However, in many other cases, pre-retirement employment is a rather undesired 'non-career bridge job' associated with part-time work, low wages and temporary contracts with different employers, and the main reason behind it may be to avoid financial insecurity derived from lack of access to adequate retirement income (Alcover, 2017). Increasing pension freedom has resulted in an increasing number of active members of occupational private pensions and DC retirement plans. According to results from the Occupational Pension Schemes Survey of 2018, displayed by the ONS (available at http://ons. gov.uk), the number of occupational pensions in payment increased from eight to ten million between 2008 and 2018. The number of active members remained stable around ten million until 2013 and then increased to 17.3 million by 2018 . While active members of occupational pensions in the public sector increased moderately from 5.4 million to 6.3 million, in the private sector the number rose from 3.6 million in 2008 to 11 million in 2018. Another significant change had to do with the type of pension. There has been a remarkable increase in active membership of occupational DC retirement plans in the private sector. From 1 million in 2008 to 9 million in 2018, most likely favoured by the introduction of the workplace pension reforms of October 2012 (automatic enrolment). Conversely, DB occupational plans have decreased in the private sector from 2.6 million in 2008 to $1.1 \mathrm{mil}-$ lion in 2018. The number of active members in the public sector is 6.3 million (mostly DB).

Providing results from our research covering the booming period of the British economy from 1991 to 2007 is still valid for the following decades, all the above-mentioned trends should have contributed to further increasing the pension income gap between highly educated male workers and the rest, particularly women. Recent research suggests that this is likely to be the case. For instance, a policy paper for the Commission on a Gender-Equal Economy by Jonquil Lowe (2020) warns that disadvantages faced by women in the labour market result in a 17 per cent gender pay gap and a 36 per cent gender pension gap. Such disadvantages are mainly a consequence of the disproportionately higher likelihood of women taking on unpaid care responsibilities (Lowe, 2020).

Expectations for the next decade are that manufacturing jobs and value-added jobs will continue to vanish because of Brexit (Bailey et al., 2019; Thissen et al., 2020), and a hypothetical upsurge of the financial sector will not suffice to cover for that loss. Additional liberalisation and deregulation of the labour market(s) will increase the pressure on the less-educated and on women to remain attached to employment, avoiding the penalties derived from pension reforms. Under such a context, the observed trend of increasing precarity among British seniors (Lain et al., 2019) is likely to spread even further, unless effective policies oriented to 
increase the employment opportunities of older workers are implemented (Phillipson et al., 2016). In this vein, further research on bridging employment strategies and on employment past retirement age (Lain and Vickerstaff, 2014) should be particularly valuable for policy making. However, political inertia related to the idiosyncratic institutional characteristics of the UK welfare state of the liberal type are a barrier to the implementation of adequate reforms to the existing system (Blackham, 2017; Walker, 2018; Martinelli and Pearce, 2019).

\section{Notes}

1 Felstead et al. (2007) report that the gap between the demand and supply at entry into the labour market for those without any qualifications is about 5 million workers.

2 For Eurostat statistics, see https://ec.europa.eu/eurostat.

3 Individuals reporting retirement without reporting any sources of pension income are considered as inactive. Additionally, those who report being sick or disabled or 'other state' are defined as inactive.

4 To completed compulsory education group belong such educational degrees as Certificate of Secondary Education (CSE) and the precursor of secondary modern school and they are characterised by lack of externally set end and school examinations which in turn leads to lack of any nationally recognised qualifications.

5 We also used the cohort metric square. However, because in both models this model specification does not improve the model fit, we do not introduce the cohort metric square into our models.

6 To test for the changes over the cohorts for the rest of the education groups, we tested the equation $\beta_{0}$

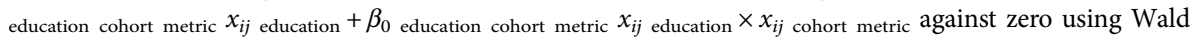
test statistics.

7 See Note 3.

$8 \beta_{1 \text { tertiary education }} x_{i j}$ tertiary education $(=$ Time $\times$ Cohort $) \times$ Research window (in years $) \times$ Months after retirement $(5$ years $\times 12)=0.35 \times 15 \times 62=315$.

9 The results for educational groups are even more pronounced if we consider disability pension as pension income.

\section{References}

Alcover CM (2017) Bridge employment: transitions from career employment to retirement and beyond. In Alcover C, Parry E and McCarthy J (eds), The Palgrave Handbook of Age Diversity and Work. London: Palgrave Macmillan, pp. 225-262.

Alderson AS (1999) Explaining deindustrialization: globalization, failure, or success? American Sociological Review 64, 701-721.

Arulampalam W, Gregg P and Gregory M (2001) Unemployment scarring. Economic Journal 111, 577584.

Bailey D, Driffield N and Kispeter E (2019) Brexit, foreign investment and employment: some implications for industrial policy? Contemporary Social Science 14, 174-188.

Banks J and Blundell R (2005) Private pension arrangements and retirement in Britain. Fiscal Studies 26, 35-53.

Banks J and Smith S (2006) Retirement in the UK. Oxford Review of Economic Policy 22, 40-56.

Banks J, Blundell R, Disney R and Emmerson C (2002) Retirement, pensions and the adequacy of saving: a guide to the debate. Briefing Note 29. The Institute for Fiscal Studies, London.

Belfield CR and Wei X (2004) Employer size-wage effects: evidence from matched employer-employee survey data in the UK. Applied Economics 36, 185-193.

Black J (2004) Britain Since the Seventies. Politics and Society in the Consumer Age. London: Reaktion Books.

Blackham A (2017) Addressing the ageing workforce: a critical examination of legal policy objectives and values in the United Kingdom. Ageing \& Society 37, 1362-1393. 
Blackwell L (2001) Occupational sex segregation and part-time work in modern Britain. Gender, Work \& Organization 8, 146-163.

Blossfeld HP and Buchholz S (2011) Aging Populations, Globalization and the Labor Market: Comparing Late Working Life and Retirement in Modern Societies. Cheltenham, UK: Edward Elgar.

Blossfeld HP, Mills M, Buchholz S, Hofacker D, Bernardi F and Hofmeister H (2008) Converging divergences? An international comparison of the impact of globalization on industrial relations and employment careers. International Sociology 23, 561-595.

Blundell R and Johnson P (1999) Pensions and retirement in the UK. In Gruber J and Wise D (eds), Social Security and Retirement Around the World. Chicago, IL: University of Chicago Press, pp. 403-435.

Blundell R, Meghir C and Smith S (2002) Pension incentives and the pattern of early retirement. Economic Journal 112, 153-170.

Blundell R, Dearden L and Sianesi B (2004) Evaluating the Impact of Education on Earnings in the UK: Models, Methods and Results from the NCDS. Working Paper No. 03/20. The Institute for Fiscal Studies, London.

Brauns H and Steinmann S (1997) Educational reform in France, West-Germany, the United Kingdom and Hungary: updating the CASMIN educational classification. Mannheimer Zentrum für Europäische Sozialforschung, Mannheim, Germany, MZES Working Paper 21.

Breen R (1997) Risk, recommodification and stratification. Sociology 31, 473-489.

Brooke L and Taylor P (2005) Older workers and employment: managing age relations. Ageing \& Society 25, 415-429.

Brown P (1995) Cultural capital and social exclusion: some observations on recent trends in education, employment and the labour market. Employment and Society 9, 29-51.

Browne J (2006) Sex Segregation and Inequality in the Modern Labour Market. Bristol, UK: Policy Press.

Budd A and Campbell N (1998) The roles of the public and private sectors in the UK pension system. In Feldstein M (ed.), Privatizing Social Security. Chicago, IL: University of Chicago Press, pp. 99-134.

Bynner J (1998) Youth in the information society: problems, prospects and research directions. Journal of Education Policy 13, 433-442.

Castells M (2000) The Rise of the Network Society. The Information Age. Oxford: Blackwell Publishers.

Cesaratto S (2006a) Pensions and distribution in an ageing society: a non-conventional view. In Eckhard $\mathrm{H}$, Arne $\mathrm{H}$ and Achim T (eds), Wages, Employment, Distribution and Growth. London: Palgrave Macmillan, pp. 181-205.

Cesaratto S (2006b) Transition to fully funded pension schemes: a non-orthodox criticism. Cambridge Journal of Economics 30, 33-48.

Clark T (2006) OECD Thematic Review of Tertiary Education: Country Report: United Kingdom. London: Department for Education and Skills.

Coates D and Hillard J (1986) The Economic Decline of Modern Britain: The Debate Between Left and Right. Brighton, UK: Wheatsheaf Books.

Coulter S (2016) The UK labour market and the 'great recession'. In Myant M, Theodoropoulou S and Piasna A (eds), Unemployment, Internal Devaluation and Labour Market Deregulation in Europe. Brussels: European Trade Union Institute, pp. 197-227.

Coyle A (2005) Changing times: flexibilization and the re-organization of work in feminized labour markets. The Sociological Review 53, 73-88.

Dewilde C (2012) Lifecourse determinants and incomes in retirement: Belgium and the United Kingdom compared. Ageing \& Society 32, 587-615.

Disney R and Emmerson C (2005) Public pension reform in the United Kingdom: what effect on the financial well-being of current and future pensioners? Fiscal Studies 26, 55-81.

Disney R, Emmerson CW and Smith S (2003) Pension Reform and Economic Performance in Britain in the 1980s and 1990s. Cambridge: National Bureau of Economic Research.

Dunning JH (2002) Regions, Globalization, and the Knowledge-based Economy. Oxford: Oxford University Press.

Elsby MW, Shin D and Solon G (2016) Wage adjustment in the Great Recession and other downturns: evidence from the United States and Great Britain. Journal of Labor Economics 34, S249-S291.

Evandrou M and Falkingham J (2009) Pensions and income security in later life. In Hills J, Sefton T and Stewart K (eds), Towards a More Equal Society?: poverty, inequality and policy since 1997. Southampton: Policy Press, pp. 157-177. 
Fagan C, Halpin B and O'Reilly J (2005) Service sector employment in Germany and the UK. Journal of Applied Social Science Studies/Zeitschrift für Wirtschafts- und Sozial wissenschaften, Schmollers Jahrbuch 125, 97-108.

Falkingham J (1989) Dependency and ageing in Britain: a re-examination of the evidence. Journal of Social Policy 18, 211-233.

Feldstein M and Siebert H (2009) Social Security Pension Reform in Europe. Chicago, IL: University of Chicago Press.

Felstead A, Gallie D, Green F and Zhou Y (2007) Skills at Work in Britain, 1986 to 2006. Oxford: ESRC Centre on Skills, Knowledge and Organisational Performance.

Foray D and Lundvall B-ä (1998) The knowledge-based economy: from the economics of knowledge to the learning economy. In Neef D, Siesfeld T, Siesfeld GA and Cefola J (eds), The Economic Impact of Knowledge. Boston: Routledge, pp. 115-121.

Foster L (2011) Privatisation and pensions: what does this mean for women? Journal of Poverty and Social Justice 19, 103-115.

Foster L and Heneghan M (2018) Pensions planning in the UK: a gendered challenge. Critical Social Policy 38, 345-366.

Georgosouli A (2014) Payment Protection Insurance (PPI) misselling: some lessons from the UK. Connecticut Insurance Law Journal 21, 261-288.

Ginn J and Arber S (1991) Gender, class and income inequalities in later life. British Journal of Sociology 42, 369-396.

Ginn J and Arber S (1993) Pension penalties: the gendered division of occupational welfare. Work, Employment and Society 7, 47-70.

Ginn J and Arber S (1998) How does part-time work lead to low pension income. In O'Reilly J and Fagan C (eds), Part-time Prospects: An International Comparison of Part-time Work in Europe, North America and the Pacific Rim. London: Routledge, pp. 156-174.

Ginn J and Arber S (2001) Pension prospects of minority ethnic groups: inequalities by gender and ethnicity. British Journal of Sociology 52, 519-539.

Golsch K, Haardt D and Jenkins SP (2006) Late careers and career exits in Britain. In Blossfeld H-P, Buchholz S and Hofäcker D (eds), Globalization, Uncertainty and Late Careers in Society. London: Routledge, pp. 183-209.

Green F, Machin S and Manning A (1996) The employer size-wage effect: can dynamic monopsony provide an explanation? Oxford Economic Papers 48, 433-455.

Gregg P and Wadsworth J (2010) Employment in the 2008-2009 recession. Economic and Labour Market Review 4, 37-43.

Gregory M and Jukes R (2001) Unemployment and subsequent earnings: estimating scarring among British men 1984-94. Economic Journal 111, 607-625.

Hall PA and Soskice D (2001) Varieties of Capitalism: The Institutional Foundations of Comparative Advantage. Oxford: Oxford University Press.

Hansen H (2000) Schemes for Early Retirement from the Labour Market in Eight Countries. Copenhagen: DNISR.

Harkness S and Waldfogel J (2003) The family gap in pay: evidence from seven industrialized countries. Research in Labor Economics 22, 369-414.

Harris K, Krygsman S, Waschenko J and Laliberte Rudman D (2018) Ageism and the older worker: a scoping review. The Gerontologist 58, 1-14.

Higher Education Funding Council for England (2001) Supply and Demand in Higher Education. Bristol, UK: Higher Education Funding Council for England.

Holman DJ, Foster L and Hess M (2020) Inequalities in women's awareness of changes to the State Pension Age in England and the role of cognitive ability. Ageing \& Society 40, 144-161.

Kitson M and Michie J (1996) Britain's industrial performance since 1960: underinvestment and relative decline. Economic Journal 106, 196-212.

Kuznets S (1955) Economic growth and income inequality. American Economic Review 45, 1-28.

Ladipo D and Wilkinson F (2002) More pressure, less protection. In Burchell B, Ladipo D and Wilkinson F (eds), Job Insecurity and Work Intensification. London: Routledge, pp. 8-38.

Lain D (2012) Working past 65 in the UK and the USA: segregation into 'Lopaq' occupations? Work, Employment and Society 26, 78-94. 
Lain D (2016) Reconstructing Retirement: Work and Welfare in the UK and USA. Bristol, UK: Policy Press.

Lain D and Vickerstaff S (2014) Working beyond retirement age: lessons for policy. In Harper S and Hamblin K (eds), International Handbook on Ageing and Public Policy. Cheltenham, UK: Edward Elgar Publishing, pp. 242-255.

Lain D, Airey L, Loretto W and Vickerstaff S (2019) Understanding older worker precarity: the intersecting domains of jobs, households and the welfare state. Ageing \& Society 39, 2219-2241.

Loretto W and Vickerstaff S (2015) Gender, age and flexible working in later life. Work, Employment and Society 29, 233-249.

Loretto W, Duncan C and White PJ (2000) Ageism and employment: controversies, ambiguities and younger people's perceptions. Ageing \& Society 20, 279-302.

Lowe J (2020) Pensions and gender equality. Commission on a Gender-Equal Economy, Policy Paper for the Commission on a Gender-Equal Economy. Women's Budget Group. Paper 3.

Lundberg M and Squire L (2003) The simultaneous evolution of growth and inequality. Economic Journal $113,326-344$.

Mann K (2007) Activation, retirement planning and restraining the 'third age'. Social Policy and Society 6, 279-292.

Martin G, Dymock D, Billett S and Johnson G (2014) In the name of meritocracy: managers' perceptions of policies and practices for training older workers. Ageing \& Society 34, 992-1018.

Martinelli L and Pearce N (2019) Basic income in the UK: assessing prospects for reform in an af austerity. Social Policy and Society 18, 265-275.

Molenberghs G and Verbeke G (2005) Models for Discrete Longitudinal Data. New York, NY: Springer.

Parry E and Wilson DB (2014) Career transitions at retirement age in the United Kingdom: bridge employment or continued career progression?. In Alcover CM, Topa G, Parry E, Fraccaroli F and Depolo M (eds), Bridge Employment: A Research Handbook. London: Routledge, pp. 164-179.

Phillipson C (2019) 'Fuller' or 'extended' working lives? Critical perspectives on changing transitions from work to retirement. Ageing \& Society 39, 629-650.

Phillipson C, Vickerstaff S and Lain D (2016) Achieving fuller working lives: labour market and policy issues in the United Kingdom. Australian Journal of Social Issues 51, 187-203.

Platts LG, Corna LM, Worts D, McDonough P, Price D and Glaser K (2019) Returns to work after retirement: a prospective study of unretirement in the United Kingdom. Ageing \& Society 39, 439-464.

Rake K, Falkingham J and Evans M (2000) British pension policy in the twenty-first century: a partnership in pensions or a marriage to the means test? Social Policy and Administration 34, 296-317.

Regini M (2000) The dilemmas of labour market regulation. In Esping-Andersen G and Regini M (eds), Why Deregulate Labour Markets? Oxford: Oxford University Press, pp. 11-28.

Reynaud E (2000) Social Dialogue and Pension Reform: United Kingdom, United States, Germany, Japan, Sweden, Italy, Spain. Geneva: International Labour Organization.

Rowthorn R and Coutts K (2004) De-industrialisation and the balance of payments in advanced economies. Cambridge Journal of Economics 28, 767-790.

Rubinstein Y and Weiss Y (2006) Post schooling wage growth: investment, search and learning. In Hanushek EA and Welch F (eds), Handbook of the Economics of Education. Amsterdam: Elsevier, pp. $1-67$.

Sefton T, Evandrou M, Falkingham J and Vlachantoni A (2011) The relationship between women's work histories and incomes in later life in the UK, US and West Germany. Journal of European Social Policy 21, 20-36.

Shavit Y and Blossfeld H-P (1993) Persistent Inequality: Changing Educational Attainment in Thirteen Countries. Boulder, CO: Westview Press.

Sherman HJ and Sherman PD (2018) Inequality, Boom, and Bust: From Billionaire Capitalism to Equality and Full Employment. London: Routledge.

Singelmann J (1978) From Agriculture to Services. The Transformation of Industrial Employment. Beverly Hills, CA: Sage.

Snower DJ (1999) Causes of Changing Earnings Inequality. Bonn, Germany: IZA.

Soskice D (1999) Divergent production regimes: coordinated and uncoordinated market economies in the 1980s and 1990s. In Kitschelt H, Lange P, Marks G and Stephens JD (eds), Continuity and Change in Contemporary Capitalism. New York, NY: Cambridge University Press, pp. 101-134. 
Stone KVW (2006) Flexibilization, globalization, and privatization: three challenges to labour rights in our time. Osgoode Hall Law Journal 44, 77-104.

Taylor-Gooby P (2006) UK pension reform: a test case for a liberal welfare state. In Bonoli G and Shinkawa T (eds), Ageing and Pension Reform Around the World. Evidence from Eleven Countries. Cheltenham, UK: Edward Elgar, pp. 116-136.

Thissen M, van Oort F, McCann P, Ortega-Argilés R and Husby T (2020) The implications of Brexit for UK and EU regional competitiveness. Economic Geography 96, 397-421.

Van Dalen HP, Henkens K and Schippers J (2009) Dealing with older workers in Europe: a comparative survey of employers' attitudes and actions. Journal of European Social Policy 19, 47-60.

Walker A (1999) The third way for pensions (by way of Thatcherism and avoiding today's pensioners). Critical Social Policy 4, 511-527.

Walker A (2018) Why the UK needs a social policy on ageing. Journal of Social Policy 47, 253-273.

Walker A and Foster L (2006) Caught between virtue and ideological necessity. A century of pension policies in the UK. Review of Political Economy 18, 427-448.

Witt MA and Jackson G (2016) Varieties of capitalism and institutional comparative advantage: a test and reinterpretation. Journal of International Business Studies 47, 778-806.

Yang X, Minford P and Meenagh D (2021) Inequality and economic growth in the UK. Open Economies Review 32, 37-69.

Cite this article: Veira-Ramos A, Schmelzer P (2023). Income growth in the United Kingdom during late career and after retirement: growing inequalities after deindustrialisation, educational expansion and development of the knowledge-based economy. Ageing \& Society 43, 393-420. https://doi.org/10.1017/ S0144686X21000581 